\title{
READERS
Insight
}

Journal of Management Info (JMI)

ISSN:2313-3376

www.readersinsight.net/jmi

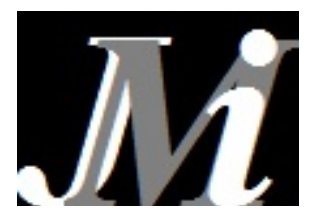

\section{A study on co-integration of Pakistani stock market with selected Asian stock markets}

\author{
Anjum Shezad ${ }^{1 *}$, Farzand Ali Jan², Saqib Gulzar³ ${ }^{3}$ M. Akram Ansari ${ }^{4}$ \\ 1,2,3 Department of Management Sciences, Comsats Institute of Information Technology, Attock, Pakistan \\ ${ }^{4}$ University of Sindh, Jamshoro, Pakistan
}

* Corresponding author: anjum@ciit-attock.edu.pk

\begin{abstract}
Pakistani Equity Market has seen many ups and downs during the last two decades. The local investors are feeling insecure in indigenous investment. The reasons are political instability, severe power crises and terrorism which compelled the local investors to go across boarder and explore the multiple option of investment in international securities to minimize the investment risk. The main purpose and scope of this study is to explore causal and dynamic linkages of Karachi Stock Exchange, KSE-100 index (Pakistan) with emerging stock markets of Nikkei-225 (Japan), Shanghai Stock Exchange, SSE (China), Kuala Lumpur Stock Exchange, KLSE (Malaysia) and Taiwan Stock Exchange Corporation, TSEC Taiwan. The most recent data is taken from January 2001 to December 2013. Monthly stock index observations are taken. Descriptive statistics, Correlation Analysis, Unit Root Test, VAR, Co-integration Test, VECM Test are used to identify the presence of short-term as well as long-term associations. Empirical results indicate that KSE-100 is a volatile market and have suitable level of returns. Moreover, KSE-100 index has no long term relationship with Japan, Malaysia, Taiwan and China but Taiwan, China and Japan has short run relationships to $\mathrm{KSE}$. The findings conclude that there is a further need of future study to explore the factors of economic integration amongst these equity markets. The study overall exhibits awareness not only for economic and financial decision makers but also for international as well as regional investors about the benefit opportunities of portfolio diversification in these equity markets, funds management and trends of the stock market.
\end{abstract}

\section{ARTICLE INFORMATION}

Received: 25 August 2014

Revised: $\quad 25$ November 2014

Accepted: 25 December 2014

DOI:

http://dx.doi.org//10.31580/jmi.v4i1.23

\section{Introduction and background of the study}

The stock market is known as the market in which shares of publicly held companies are issued and traded either through exchanges or over-the-counter markets. It is also known as the equity market, the stock market is one of the most vital components of a free-market economy, as it provides companies with access to capital in exchange for giving investors a slice of ownership in the company. The stock market makes it possible to grow small initial sums of money into large ones, and to become wealthy without taking the risk of starting a business or making the sacrifices that often accompany a high-paying career.

In today's modern economy, stock markets play an active role, since it acts as an intermediary between lenders and borrowers. An efficient stock market may accelerate the development process in an economy through two main channels of increasing savings and efficient allocation of resources. The investment on equity markets has become popular in developed countries like the US and European countries since the last many decades. Although these countries have even experienced fluctuations during stability, the investments increased especially in high tech sectors of stock markets (Gallo \& Otranto, 2007).

The emerging markets across the globe are integrating each other in response to the globalization and enrichment in the overall economic conditions with the developed equity markets and it also stimulate to increase their movements accordingly with developed stock markets. Nevertheless, the emerging stock markets are significantly different in financial dynamics for integration and these equity markets are not homogenous (Bekaert \& Harvey, 1995).

After the work of Markowitz (1952) the phenomena of portfolio selection become almost the core of all financial investments and variance optimization is still consider while the formulation of portfolio. Selection of portfolio is all about picking different securities form different markets in your investment baskets. According to him in the selection process the important consideration is co-movement between different selected stocks. Due to increase in financial innovation, services proliferation, globalization, homogenizations, harmonization, competition, technology and changing demographic patters, phenomena of traditional investments has been changed. Now investors are looking cross boundaries investment and following the well-known fact that investment always needs safe heaven either local plus/or cross boundaries. The financial portfolio holders are always having keen interest in relative risk and return which may be accomplished by the international portfolio diversification.

It can be summarizing that economic, financial, regional, international policies and specific variables are those internal and external factors on which the speed and nature of the financial process of integration both depend on (Chan Charat \& Valad Khani, 2007).

During a depression, investors switch their investment funds to more protective stocks, such as non-cyclical consumer goods sector. The 
most serious international recession since the Second World War led to either oil price shocks or political instability has triggered by the Middle East and North African countries (MENA) (Cheng et al., 2010; Hamilton 1983, 1996; Hamilton 2003, 2009; Hamilton Herrera, 2004).

The Capital Asset Pricing Model was commenced by Sharp in 1963, which suggested that it is impossible to eliminate the systematic risk, (or 'market risk'). As investors become more risk averse, subsequently risk diversification continues to be their indispensable concern. To curtail the prevailing situation the remedial measurement which the investor may likely to be taken to invest in various equity markets owe the notion for international diversification, whereas there general argument which may be taken that investments in international equity markets not only offer the additional and ample potential profit but simultaneously reduce the total portfolio investment risk.

In a globally integrated market, monitoring as well controlling contagion of one equity market of the other equity markets have been of great concerned by the investors and academicians to avoid the superfluous effects. It may be experimented that if diverse stock markets of globe are co-movement i.e. which exist long-term relationship, in this way benefit of diversification may be taken by investing in different equity markets cannot be attained. Nevertheless, if equity markets have been seen no co-movement in short run then benefit of portfolio diversification will be existing for shorter sphere. For this reason it may be pertinent that policymakers, investors and academicians must be acquainted with the co-movements of stock markets in globe (Arshad, Shah \& Abdullah, 2007).

Due to liberalization of capital markets and the development of new varieties of financial instruments, the level of international diversification of portfolios has increased. Since the work of Grubel (1968) on the benefits of international diversification of portfolio, the relationship among the various stock markets has been studied extensively. Such linkages may be due to common macroeconomic policies or may be without any common link between the equity stock markets of the countries. However this does have implications on portfolio diversification and macroeconomic policy formulation of a country.

Abbas, Khan and Shah (2013) has pointed out that as for as the matter regarding portfolio risk reduction is concerned, International portfolio diversification has a unique aspect which may be seen as returns of securities had less correlation with other foreign countries than within an indigenous country. This is owing to numerous factors e.g. institutional, financial, economic, psychological and even political. Due to all these factors affect security returns inclined to move an enormous deal across countries with low correlation between international securities.

Capital markets not only drive the savings in such an efficient way towards the portfolios for investment. It may also assist to build up a smooth investment culture in an economy. The trends for investments have quickly changed the emerging stock markets of globe: because of this reason, therefore, economies growing and developing smoothly. That may be lead towards associated addition between those emerging economies. During this century business as well as economies which are going rapidly towards more globalization has extremely enhanced the volume for investments into financial instruments. Owing to increase in the globalization, the international stock markets are rushing towards integration, like ASEAN, NAFTA, EU, MENA, and Scandinavian countries. That aspect is a positive signal for the global economic growth which may reduce that risk for contagion effects due to financial crisis, mainly if that which created from the larger stock markets sides (Cheng, 2010; Ewing, 2002; Gallo \& Otranto, 2007; Mandaci, 2011).

The equity market of KSE-100 index Pakistan persisted greatly volatile since the last 50 months. Three extreme financial crises were witnessed during that period. First, in March, 2005the equity market of Pakistan was crashed. Second, in the $2^{\text {nd }}$ quarter of the year 2006 collapse was witnessed. Third, from May, 2008 to Jan, 2009 crash was observed which was pointed as the most serious one. KSE100index was fallen more than 10 thousand points in this period.
Again a very major crash was observed in Jan, 2013 when KSE-100 index dropped more than 500 points that fall happens to be the second-largest in Pakistan's history (Economic Survey of Pakistan 2008-09 \& 2012-2013).

The novelty of this study is that it has been undertaken on the diverse mix economies. This study will explore the integration of developed, developing and emerging markets. The investors may gain advantage of portfolio diversification by having information of diverse mix economies.

\section{Literature review}

In 1990 the investigation of Subrahmanyam and Mathur commemorated the relationship among the Nordic (Sweden, Norway, Denmark, Finland) and US equity markets, and revealed that, US stock markets have some influence on Denmark but no effect at Sweden, Finland and Norway. Stock market of Sweden does Granger Cause to the Norway as well as Finland. Equity markets of Denmark, Norway as well as Finland, as depicted do not Granger cause to other equity market. Also, it was examined that between the Nordic stock markets, the integration level there is lower.

In 1992 Kasa examined that there stand a sole common trend that may compel the equity markets of Germany, Japan, USA, England and Canada. In addition, he suggested that there may present a long-run co-integration relationship among these equity markets.

In 1999 Roca examine the interrelatedness between stock markets of Korea, Japan, U.S, U.K, Taiwan, Singapore, Hong Kong and Australia by evaluating Co-integration test. It was suggested that there was present no long term relationship among Australia and other equity markets which are being study.

In $2002 \mathrm{Ng}$ investigated the facts concerning to find co-integration between ASEAN equity markets (Indonesia, Philippines, Malaysia and Singapore and Thailand). Study was comprises on the stock prices for the period started from 1988 to 1997 . The study was also investigated that there present no long-term co-integration relationship between the ASEAN equity market where only the relationship was found in short span of periods. The result the from Correlation analysis shows that integration is increasing whereas time varying analysis illustrates that some equity markets are advancing to be closer to co-integrate with the Singapore.

In 2004 Haron, shamsuddin and Azmi also searched the co-movement among Malaysian stock market and his main trading partners (Japan, US and Singapore). The data which was started from Jan, 1995 to June, 1997 was used and apply Impulse response analysis, Cointegration, Vector Error Correction Model (VECM) and to discover relationship among countries which are being study. It was illustrated that no long-term steady co-movement was found before the implementation of capital measures which are to be controlled, whilst stable co-movement relationship was found after applying capital measures which are to be controlled between countries which are being studied. Also an attempt has also been made to study the relationship between Malaysian stock market as well as Tiger stock markets.

In 2005 Marashdeh studied long-term co-movement between MENA countries as well as developed countries like UK, US and Germany. To examine the relationship auto regressive distributed lag approach was used. It was concluded that MENA countries have the attribution of inter dependent contrary to this MENA counties they have not shown any long term relationship with the developed countries.

In 2007 Glezakos et al., has compared the world's major equity markets i.e. England, USA, France, Italy, Germany, Holland, Spain, Japan and Belgium with Athens stock market. He further explored the inter-relatedness among these markets. The result depicted that these markets remained integrated at 1st level of difference furthermore, there were the detection of multi-directional spillover effects by these markets.

Hasan, Abdullah \& Saleem (2008) examined the existence of longterm co-integration movement between Pakistani equity market KSE100 index and of US, UK, Australia Germany, France, Canada, Italy 
and Japan. Study comprises weekly index time series data of seven years which was being started from Jan, 2000 to Dec, 2006.

Arouri \& Jawadi (2009) searched long/ short-term relationship among 02 developing nations (Mexico, Philippines). Monthly data was used which was started from Dec, 1998 to Dec, 2008. Multivariate cointegration technique which was applied to explored long-term comovement among Philippines and Mexico stock market with global stock market. It was investigated developing equity markets shown integration with global equity market. It was illustrated that Mexico stock market was highly integrated with global equity market as compared to Philippines stock market.

In 2011 Ampomah concluded that South African stock markets were shown independency with world's major stock markets whereas the South African market shown dependency on foreign Stock markets economy. The study reveals that there was found no relationship among stock markets of these countries. Furthermore, the favorable information is exhibited for the help of foreign investors' as well concerned researchers. Nevertheless, there is not ample facility available for local investors to ripe fruit from portfolio investment. In recent time's extensive research is being conducted on interdependence of regional stock markets.

Cheung \& Ho (1991) and Cheung (1993) conducted study on eleven emerging Asian stock markets and developed markets and found that there was very little correlation among the Asian market group and the developed markets group.

Hamid \& Hassan (2011) studied to explore the causal or dynamic linkages of KSE-100 with emerging equity markets of Malaysia, India, Turkey, China, Brazil, Hong Kong, Thailand and Indonesia the study was also consist of the developed equity markets of France, Japan, USA and UK. The study was comprises from the period starting by Jan, 1998 to Dec, 2008. i.e. 132 monthly stock indices observation were used.

In 2012 Thao \& Daly commemorated in the paper that studied the long-run relationship among six equity markets in the Southeast Asian region, namely Thailand, Malaysia, Singapore, Philippines, Indonesia and Vietnam using daily market indices collected over the period 2006-2010. Three testing methods used in the paper include; multivariate co-integration test based on vector autoregressive (VAR) model bi-variate co-integration test based on residuals; and cointegration tests with the presence of structural breaks.

\section{Methodology}

The data consist of monthly stock prices indices for period started from Jan, 2001 to 2013 Dec, of KSE-100 Index Pakistan (Karachi Stock Exchange) with Asian equity markets of Nikkei-225 (Japan), Shanghai Stock Exchange, SSE (China), Kuala Lumpur Stock Exchange, KLSE (Malaysia) and Taiwan Stock Exchange Corporation, TSEC Taiwan. The data of these equity markets indexes has been taken from the several web sources i.e. Yahoo Finance, Market watch etc. The data is consisting of monthly stock Index prices which is consist of 156 months.

Table 1: Indices of Pakistani Equity Market and selected Asian Markets

\begin{tabular}{ll}
\hline Country Name & Index \\
\hline Pakistan & Karachi Stock Exchange, KSE-100 index \\
Japan & Nikkei-225 \\
China & Shanghai Stock Exchange, SSE \\
Malaysia & Kuala Lumpur Stock Exchange, KLSE \\
Taiwan & Taiwan Stock Exchange Corporation, TSEC \\
\hline
\end{tabular}

\section{Hypotheses}

Based on above problems and data following hypothesis are developed.

H1: KSE-100 Index Karachi Stock Exchange (Pakistan) has significant correlation with Selected Asian Stock markets.

H2: KSE-100 Index Karachi Stock Exchange (Pakistan) and Selected Asian Stock markets do not contain a unit root, the data is stationary. H3: KSE-100 Index Karachi Stock Exchange (Pakistan) has long term relationship with Selected Asian Stock markets.

Table 4: Unit Root Test
H4: KSE-100 Index Karachi Stock Exchange (Pakistan) has short term relationship with Selected Asian Stock markets.

\section{Descriptive statistics}

Descriptive statistics is used to examine the behavior of stock returns. Table 1exhibits results from descriptive statistics of stock indices of the Asian Stock Markets and the Pakistani stock market. There are mean, standard deviation, skewness, kurtosis and range etc are included.

Table 2: Descriptive Statistics

\begin{tabular}{llllll}
\multicolumn{5}{l}{ Table 2: Descriptive Statistics } \\
\hline Mean & 0.020290 & 0.006985 & 0.002130 & 0.003874 & 0.004579 \\
Median & 0.021724 & 0.011623 & 0.002766 & 0.007914 & 0.009680 \\
Maximum & 0.241114 & 0.127032 & 0.120888 & 0.146018 & 0.223115 \\
Minimum & -0.448796 & -0.165142 & -0.272162 & -0.214422 & -0.215030 \\
Std.Dev. & 0.081801 & 0.041489 & 0.058798 & 0.048779 & 0.066908 \\
Skewness & -1.323924 & -0.618836 & -0.857538 & $-0.483409-0.325648$ \\
Kurtosis & 9.778037 & 5.127322 & 5.199682 & 4.939586 & 4.103579 \\
Jarque-Bera & 328.7492 & 37.60594 & 48.30138 & 28.96317 & 10.19453 \\
Probability & 0.000000 & 0.000000 & 0.000000 & 0.000001 & 0.006113 \\
Sum & 3.023156 & 1.040736 & 0.317396 & 0.573346 & 0.682239 \\
SumSq.Dev. & 0.990336 & 0.254752 & 0.511671 & 0.349773 & 0.662541 \\
Observations 149 & 149 & 149 & 149 & 149 \\
\hline
\end{tabular}

The test of Descriptive statistics is used at the 05 equity markets period started from 2001 to 2013. The result from the statistical analysis are shown at Table-2 specifies the descriptive statistics of market returns series concerning to Pakistan and selected Asian stock markets. The results disclose that the Avg. return of KSE-100 is $2.02 \%$ and at a specific level of (SD) standard deviation of $08.18 \%$ and Malaysian Stock Exchange has $0.69 \%$ return at $4.14 \%$ level of risk. Likewise, the Japanese Stock Exchange is producing $0.21 \%$ return at $5.87 \%$ surface of risk. Chinese Stock Exchange is providing $0.38 \%$ Avg. monthly return at $4.87 \%$ level of risk. Whereas Taiwan Stock Exchange is providing $0.45 \%$ Avg. monthly returns at $6.69 \%$ level of risk.

This scenario exhibits that the equity market KSE-100 Index is providing high returns at high risk level. The value from the Table 2 of skewness indicates that the returns of all the equity markets are negatively skewed.

\section{Correlation}

Results from the Table-3 shown that the hypothesis H1: has been rejected. After applying the correlation test, the results indicate that there exist no significant correlations between KSE-100 and other selected Asian markets.

\begin{tabular}{llllll}
\multicolumn{2}{l}{ Table 3: Correlation } \\
Equity Markets & KSE & NIK & MAL & SSE & TWN \\
KSE & 1 & & & & \\
NIK & 0.25970 & 1 & & & \\
MAL & 0.23329 & 0.37854 & 1 & & \\
SSE & 0.12619 & 0.15804 & 0.13559 & 1 & \\
TWN & 0.25913 & 0.52179 & 0.54988 & 0.09211 & 1 \\
\hline
\end{tabular}

*Significant at 0.01 level.

As correlation analysis does not study the cause and effect relationship so it is considered as a weaker approach. This study will further focus on several methodologies to glance the long-run as well as short-run causal as well as dynamic nature for relationship.

\section{Unit root test}

Before applying Co-integration analysis it is compulsory to check stationarity of the time series data. The Augmented Dickey Fuller test (1981) test is widely used to test the stationarity of the stock prices. To execute Co-integration Test, the condition can be perceived as that the data is to be stationary at same order. 


\begin{tabular}{|c|c|c|c|c|c|}
\hline Variable & $\begin{array}{l}\text { At Level } \\
\text { t-Statistics }\end{array}$ & P-value & $\begin{array}{l}\text { At 1stDifference } \\
\text { t-Statistics }\end{array}$ & P-value & results \\
\hline$\Delta \Delta_{\Delta} \mathrm{KSE}$ & 1.003978 & 0.9965 & -11.35798 & & \\
\hline$\Delta \Delta \mathrm{MAL}$ & 0.046335 & 0.9605 & -11.03554 & 0.0000 & Stationary at First Difference \\
\hline$\Delta \Delta^{\mathrm{NIK}}$ & -1.358456 & 0.6011 & -9.936601 & 0.0000 & Stationary at First Difference \\
\hline$\Delta \Delta$ SSE & -1.455936 & 0.5532 & -10.85564 & 0.0000 & Stationary at First Difference \\
\hline$\Delta \Delta \mathrm{TAl}$ & -2.040116 & 0.2696 & -11.05617 & 0.0000 & Stationary at First Difference \\
\hline
\end{tabular}

$1 \%$ level $\quad-3.474874,5 \%$ level $\quad-2.880987,10 \%$ level -2.577219

Note: The $1^{\text {st }}$ differential of variable is Indicated $\Delta$, The $2^{\text {nd }}$ differential of variable is Indicated $\Delta \Delta$

Null hypothesis ${ }^{*}$ Rejected at .0 .01 level of significance, Null hypothesis ${ }^{\star *}$ Rejected at 0.05 level of significance

Table 5: VAR Lag Order Selection Criteria

\begin{tabular}{llll}
\hline Lag & AIC & SC & HQ \\
\hline 0 & 71.05617 & 71.16073 & 71.09866 \\
1 & $58.40017^{*}$ & $59.02757^{*}$ & $58.65513^{*}$ \\
2 & 58.42853 & 59.57875 & 58.89594 \\
3 & 58.56249 & 60.23554 & 59.24236 \\
4 & 58.63379 & 60.82967 & 59.52612 \\
5 & 58.64695 & 61.36566 & 59.75174 \\
7 & 58.59506 & 61.83660 & 59.91231 \\
8 & 58.65891 & 62.42328 & 60.18862 \\
\end{tabular}

*indicates lag order selected by the criterion

AIC: Akaike information criterion

SC: Schwarz information criterion

$H Q$ : Hannan-Quinn information criterion

Table 6a: Multivariate Co-integration Test (Trace statistics)

\begin{tabular}{|c|c|c|c|c|c|c|}
\hline Variables & Hypothesized No. of CE(s) & Eigenvalue & Trace Statistic & 0.05 Critical Value & Prob.** & Remarks \\
\hline KSE & None * & 0.266559 & 98.83473 & 69.81889 & 0.0001 & \\
\hline MAL & At most 1 * & 0.205205 & 54.19355 & 47.85613 & 0.0113 & I race statistics provides \\
\hline NIK & At most 2 & 0.090411 & 21.12092 & 29.79707 & 0.3502 & results that there exists 2 \\
\hline SSE & At most 3 & 0.049779 & 7.475201 & 15.49471 & 0.5231 & co-integrating equations \\
\hline TWN & At most 4 & 0.000850 & 0.122404 & 3.841466 & 0.7264 & \\
\hline
\end{tabular}

Trace test indicates 2 cointegratingeqn(s) at the 0.05 level

*denotes rejection of the hypothesis at the 0.05 level

**MacKinnon-Haug-Michelis (1999) p-values

Table 6b: Multivariate Co-integration Test (Maximum Eigenvalue Statistics)

\begin{tabular}{|c|c|c|c|c|c|c|}
\hline Variables & Hypothesized No. of CE(s) & Eigenvalue & Max-Eigen & 0.05 Critical Value & Prob.** & Remarks \\
\hline KSE & None * & 0.266559 & 44.64117 & 33.87687 & 0.0018 & Max.Eigen Value statistics \\
\hline MAL & At most 1 * & 0.205205 & 33.07264 & 27.58434 & 0.0089 & provides resultsthat there \\
\hline NIK & At most 2 & 0.090411 & 13.64571 & 21.13162 & 0.3948 & exists 2 co-integrating \\
\hline SSE & At most 3 & 0.049779 & 7.352797 & 14.26460 & 0.4483 & equations at $0.05 \mathrm{critical}$ \\
\hline TWN & At most 4 & 0.000850 & 0.122404 & 3.841466 & 0.7264 & value level \\
\hline
\end{tabular}

Max-eigenvalue test indicates 2 co-integrating eqn(s) at the 0.05 level

*denotes rejection of the hypothesis at the 0.05 level

${ }^{* *}$ MacKinnon-Haug-Michelis (1999) p-values

Table 7a: Bi-Variate Co-integration Test, (Trace statistics)

\begin{tabular}{|c|c|c|c|c|c|c|}
\hline Variables & HypothesizedNo.ofCE(s) & Eigenvalue & TraceStatistic & 0.05 CriticalValue & Prob.** & Remarks \\
\hline \multirow{2}{*}{ KSE-MAL } & None & 0.020472 & 3.234465 & 15.49471 & 0.9552 & No Co-integration \\
\hline & Atmost1 & 0.001621 & 0.235290 & 3.841466 & 0.6276 & \\
\hline \multirow{2}{*}{ KSE-NIK } & None & 0.031700 & 5.199616 & 15.49471 & 0.7873 & No Co-integration \\
\hline & Atmost1 & 0.003640 & 0.528727 & 3.841466 & 0.4671 & \\
\hline \multirow{2}{*}{ KSE-SSE } & None & 0.077643 & 11.70239 & 15.49471 & 0.1718 & No Co-integration \\
\hline & Atmost1 & 0.000444 & 0.063913 & 3.841466 & 0.8004 & \\
\hline \multirow{2}{*}{ KSE-TWN } & None & 0.078611 & 14.74047 & 15.49471 & 0.0647 & No Co-integration \\
\hline & Atmost1 & 0.019591 & 2.868853 & 3.841466 & 0.0903 & \\
\hline
\end{tabular}

Trace test indicates no cointegration at the 0.05 level,

*denotes rejection of the hypothesis at the 0.05 level

**MacKinnon-Haug-Michelis (1999) p-values

Table 7b: Bi-variate Co-integration Test (Maximum Eigenvalue Statistics).

\begin{tabular}{lllllll}
\hline Variables & Hypothesized No. of CE(s) & Eigenvalue & Max- Eigenvalue Statistic & $\mathbf{0 . 0 5}$ Critical Value & Prob.** & Remarks \\
\hline \multirow{2}{*}{ KSE-MAL } & None & 0.020472 & 2.999175 & 14.26460 & 0.9468 & \multirow{2}{*}{ No Co- integration } \\
& At most 1 & 0.001621 & 0.235290 & 3.841466 & 0.6276 & \\
KSE-NIK & None & 0.031700 & 4.670889 & 14.26460 & 0.7827 & \multirow{2}{*}{ No Co-integration } \\
& At most 1 & 0.003640 & 0.528727 & 3.841466 & 0.4671 & \\
\multirow{2}{*}{ KSE-SSE } & None & 0.077643 & 11.63848 & 14.26460 & 0.1250 & \multirow{2}{*}{ No Co-integration } \\
& At most 1 & 0.000444 & 0.063913 & 3.841466 & 0.8004 & \\
KSE-TWN & None & 0.078611 & 11.87162 & 14.26460 & 0.1156 & \multirow{2}{*}{ No Co-integration } \\
& At most 1 & 0.019591 & 2.868853 & 3.841466 & 0.0903
\end{tabular}

Max-Egn value specifies no co-integration at $5 \%$ leve

${ }^{*}$ denotes the hypothesis rejection at the level of $5 \%$

**MacKinnon-Haug-Michelis (1999) p-values 


\begin{tabular}{|c|c|c|c|c|c|}
\hline ErrorCorrection & D(KSE) & D(MAL) & $\mathrm{D}(\mathrm{NIK})$ & D(SSE) & $\mathrm{D}(\mathrm{TWN})$ \\
\hline CointEq1 & $\begin{array}{l}-0.214008 \\
(0.04169) \\
{[-5.13383]}\end{array}$ & $\begin{array}{l}-0.001044 \\
(0.00268) \\
{[-0.38875]}\end{array}$ & $\begin{array}{l}0.040330 \\
(0.03994) \\
{[1.00983]}\end{array}$ & $\begin{array}{l}-0.000126 \\
(4.6 E-05) \\
{[-2.75444]}\end{array}$ & $\begin{array}{l}-0.058447 \\
(0.02588) \\
{[-2.25824]}\end{array}$ \\
\hline $\mathrm{D}(\mathrm{KSE}(-1))$ & $\begin{array}{l}0.020734 \\
(0.07825) \\
{[0.26498]}\end{array}$ & $\begin{array}{l}0.005555 \\
(0.00504) \\
{[1.10243]}\end{array}$ & $\begin{array}{l}0.143106 \\
(0.07497) \\
{[1.90897]}\end{array}$ & $\begin{array}{l}0.000199 \\
(8.6 E-05) \\
{[2.32671]}\end{array}$ & $\begin{array}{l}0.110916 \\
(0.04858) \\
{[2.28312]}\end{array}$ \\
\hline $\mathrm{D}(\mathrm{KSE}(-2))$ & $\begin{array}{l}-0.072946 \\
(0.08099) \\
{[-0.90063]}\end{array}$ & $\begin{array}{l}0.001560 \\
(0.00522) \\
{[0.29910]}\end{array}$ & $\begin{array}{l}0.119452 \\
(0.07760) \\
{[1.53936]}\end{array}$ & $\begin{array}{l}5.15 \mathrm{E}-05 \\
(8.9 \mathrm{E}-05) \\
{[0.58138]} \\
\end{array}$ & $\begin{array}{l}0.028486 \\
(0.05029) \\
{[0.56647]} \\
\end{array}$ \\
\hline $\mathrm{D}(\mathrm{MAL}(-1))$ & $\begin{array}{l}-4.396296 \\
(1.79875) \\
{[-2.44408]}\end{array}$ & $\begin{array}{l}-0.066336 \\
(0.11583) \\
{[-0.57270]}\end{array}$ & $\begin{array}{l}1.128528 \\
(1.72332) \\
{[0.65486]}\end{array}$ & $\begin{array}{l}-0.004337 \\
(0.00197) \\
{[-2.20577]}\end{array}$ & $\begin{array}{l}-0.821544 \\
(1.11680) \\
{[-0.73563]}\end{array}$ \\
\hline $\mathrm{D}(\mathrm{MAL}(-2))$ & $\begin{array}{l}1.972870 \\
(1.75349) \\
{[1.12511]}\end{array}$ & $\begin{array}{l}0.070325 \\
(0.11291) \\
{[0.62281]}\end{array}$ & $\begin{array}{l}-0.828775 \\
(1.67996) \\
{[-0.49333]}\end{array}$ & $\begin{array}{l}-0.001116 \\
(0.00192) \\
{[-0.58225]}\end{array}$ & $\begin{array}{l}-1.286779 \\
(1.08869) \\
{[-1.18195]} \\
\end{array}$ \\
\hline $\mathrm{D}(\mathrm{NIK}(-1))$ & $\begin{array}{l}0.052324 \\
(0.10555) \\
{[0.49573]}\end{array}$ & $\begin{array}{l}0.011860 \\
(0.00680) \\
{[1.74491]}\end{array}$ & $\begin{array}{l}0.127209 \\
(0.10112) \\
{[1.25798]}\end{array}$ & $\begin{array}{l}5.34 \mathrm{E}-05 \\
(0.00012) \\
{[0.46267]}\end{array}$ & $\begin{array}{l}-0.022210 \\
(0.06553) \\
{[-0.33892]}\end{array}$ \\
\hline $\mathrm{D}(\mathrm{NIK}(-2))$ & $\begin{array}{l}0.020635 \\
(0.10697) \\
{[0.19290]}\end{array}$ & $\begin{array}{l}-0.011889 \\
(0.00689) \\
{[-1.72591]}\end{array}$ & $\begin{array}{l}0.014223 \\
(0.10249) \\
{[0.13878]} \\
\end{array}$ & $\begin{array}{l}-0.000187 \\
(0.00012) \\
{[-1.59761]}\end{array}$ & $\begin{array}{l}-0.111099 \\
(0.06642) \\
{[-1.67277]} \\
\end{array}$ \\
\hline $\mathrm{D}(\operatorname{SSE}(-1))$ & $\begin{array}{l}-98.61292 \\
(78.2945) \\
{[-1.25951]}\end{array}$ & $\begin{array}{l}-1.848834 \\
(5.04171) \\
{[-0.36671]}\end{array}$ & $\begin{array}{l}-95.18482 \\
(75.0114) \\
{[-1.26894]}\end{array}$ & $\begin{array}{l}0.064472 \\
(0.08558) \\
{[0.75337]}\end{array}$ & $\begin{array}{l}7.941772 \\
(48.6110) \\
{[0.16337]} \\
\end{array}$ \\
\hline $\mathrm{D}(\operatorname{SSE}(-2))$ & $\begin{array}{l}-98.94023 \\
(77.6931) \\
{[-1.27348]}\end{array}$ & $\begin{array}{l}3.984340 \\
(5.00298) \\
{[0.79639]} \\
\end{array}$ & $\begin{array}{l}59.45557 \\
(74.4352) \\
{[0.79876]} \\
\end{array}$ & $\begin{array}{l}0.004676 \\
(0.08492) \\
{[0.05506]}\end{array}$ & $\begin{array}{l}-3.110524 \\
(48.2376) \\
{[-0.06448]} \\
\end{array}$ \\
\hline $\mathrm{D}(\mathrm{TWN}(-1))$ & $\begin{array}{l}0.378334 \\
(0.19636) \\
{[1.92672]}\end{array}$ & $\begin{array}{l}0.009796 \\
(0.01264) \\
{[0.77470]}\end{array}$ & $\begin{array}{l}0.021466 \\
(0.18813) \\
{[0.11411]}\end{array}$ & $\begin{array}{l}0.000122 \\
(0.00021) \\
{[0.56701]}\end{array}$ & $\begin{array}{l}0.130408 \\
(0.12192) \\
{[1.06966]}\end{array}$ \\
\hline $\mathrm{D}(\mathrm{TWN}(-2))$ & $\begin{array}{l}0.200876 \\
(0.18904) \\
{[1.06259]} \\
\end{array}$ & $\begin{array}{l}0.014491 \\
(0.01217) \\
{[1.19041]} \\
\end{array}$ & $\begin{array}{l}0.102826 \\
(0.18112) \\
{[0.56774]} \\
\end{array}$ & $\begin{array}{l}0.000287 \\
(0.00021) \\
{[1.38673]} \\
\end{array}$ & $\begin{array}{l}0.225658 \\
(0.11737) \\
{[1.92258]} \\
\end{array}$ \\
\hline C & $\begin{array}{l}180.6636 \\
(59.5378) \\
{[3.03444]}\end{array}$ & $\begin{array}{l}6.559006 \\
(3.83389) \\
{[1.71080]}\end{array}$ & $\begin{array}{l}-10.33889 \\
(57.0412) \\
{[-0.18125]}\end{array}$ & $\begin{array}{l}0.038528 \\
(0.06508) \\
{[0.59204]}\end{array}$ & $\begin{array}{l}20.15157 \\
(36.9654) \\
{[0.54515]}\end{array}$ \\
\hline R-squared & 0.277252 & 0.103358 & 0.121827 & 0.121936 & 0.098701 \\
\hline Adj.R-squared & 0.217922 & 0.029753 & 0.049738 & 0.049856 & 0.024714 \\
\hline Sumsq.resids & 59120591 & 245150.0 & 54266383 & 70.63265 & 22790038 \\
\hline S.E.equation & 664.2277 & 42.77239 & 636.3749 & 0.726023 & 412.4014 \\
\hline F-statistic & 4.673051 & 1.404228 & 1.689955 & 1.691676 & 1.334035 \\
\hline Loglikelihood & -1149.703 & -749.2644 & -1143.449 & -154.1587 & -1080.116 \\
\hline AkaikeAIC & 15.91374 & 10.42828 & 15.82807 & 2.276147 & 14.96049 \\
\hline SchwarzSC & 16.15897 & 10.67351 & 16.07330 & 2.521374 & 15.20572 \\
\hline Meandependent & 163.3910 & 8.677329 & 40.58199 & 0.045890 & 32.24671 \\
\hline S.D.dependent & 751.0901 & 43.42326 & 652.8169 & 0.744827 & 417.5939 \\
\hline $\begin{array}{l}\text { Determinantresidcovariance(dofadj.) } \\
\text { Determinantresidcovariance } \\
\text { Loglikelihood } \\
\text { Akaikeinformationcriterion } \\
\text { Schwarzcriterion }\end{array}$ & & $\begin{array}{l}1.23 E+19 \\
8.03 E+18 \\
-4213.539 \\
58.61013 \\
59.93844\end{array}$ & & & \\
\hline
\end{tabular}

Result from Table 4 shown that the Hypothesis H2: has been accepted for that 05 data series at $5 \%$ level of significance which leads us to proceed further and investigate the long-term relationship among all the series by using Johansen Co-integration Test (1981).

\section{VAR Lag}

Unit root and Lag selection is a pre-requisites in order to employ co-integration test. Before applying Johnson and Julius (1991) Approach, it is necessary to select out an appropriate lag length. Unrestricted VAR is estimated and following criteria from 01 to 08 periods are being used. The suitable lag length is considered where Akaike information criterion, Schwarz information criterion, HannanQuinn information criterion is found minimum. The result shown at Table-5 depicts that the proper lag length for this particular study is 1 .

\section{Johansen co-integration test}

For the subsequently step, study gets into consideration (Multivariate as well as Bi-variate Co-integration Tests).

\section{Multivariate co-integration}

Table $6 \mathrm{a}$ and Table $6 \mathrm{~b}$ shows the results of Multivariate Cointegration Test.

The Trace Statistics in comparison with the critical value shows that it is on higher side and hence it shows that there is evidence for the presence of co-integrating equation i.e. 2(two) co-integrating equations at $5 \%$.

The Max-Eigen Value is also depicted to be the greater than critical value at $5 \%$ there is also evidence for the presence of co-integrating equation i.e. 2(two) co-integrating equations at 5\% level of significance. So it also shows the existence of long term relationship among these stock markets i.e. Pakistani, Malaysian, Chinese, Taiwan and Japanese Stock Exchanges.

This test does not confer that which equity market has long-term relationship to other equity market which may be known as pair-wise co-integration. To examine the pair-wise co-integration study further applies Bi-variate co-integration Test. 


\section{Bi-variate co-integration test}

It is possible that different series are not found integrated in Multivariate Analysis but shows different results with a bi-variate analysis.

From the results shown in the Table-7a and Table-7b the Hypothesis H3 has been rejected. The test indicates that, there exist no cointegrating vectors at 5\% levels with MAL, NIK, SSE and TWN.

As far as the long run relationship is concerned; the study focuses on short-term relationship among the stock markets. So, (VECM) vector Error Correction Model will be used further to know about the short term relationship.

\section{Vector error correction model}

After exploring the long-term relationship between the selected securities variables, the study take into the investigation of short term relationship, the (VECM) Error Correction Model is applied.

From the results shown in the Table- 8 the Hypothesis $\mathrm{H} 4$ has been accepted.Table- 8 provides VECM to give explanation about shortterm co-integrating vectors. The result from (VECM) vector error correction model explains that KSE-100 has not depended upon the lagged values of its own indices.

\section{Discussion}

This research methodology and the test statistic which are applied on the data to inspect the long-term and the short-run association ship amongst the Karachi Stock Exchange, KSE-100 index (Pakistan) with developed, developing and emerging equity markets of Nikkei-225 (Japan), Shanghai Stock Exchange, SSE (China), Kuala Lumpur Stock Exchange, KLSE (Malaysia) and Taiwan Stock Exchange Corporation, TSEC Taiwan. Here is detailed discussion about each country's Equity Market with relation to Pakistani Stock Market KSE-100 Index. The result of Descriptive Statistics exhibits that the equity market KSE-100 Index is providing high returns at high risk level. KLSE is producing on an Avg. $0.69 \%$ returns is on 2nd position and the level of risk is lesser than KSE-100 also. After that, at 3rd level, the TSEC is producing decent return at certain risk level which is $0.45 \%$. SSE and Nikkie-225 are producing the returns after the turns of KSE-100 Index, KLSE and TSEC i.e $0.38 \%$ and $0.21 \%$ respectively.

\section{Conclusion}

This thesis focuses on integration among East Asian developed, developing and emerging stock markets including Nikkei-225 (Japan), Shanghai Stock Exchange, SSE (China), Kuala Lumpur Stock Exchange, KLSE (Malaysia) and Taiwan Stock Exchange Corporation, TSEC Taiwan with reference to Karachi Stock Exchange, KSE-100 index (Pakistan). EAC (East Asian markets) have revealed poor integration among the equity markets. These results can be referring to the geographical and trade associations which are present between these countries. Pakistan and China have very strong relations but because of tough trade regulations of the trade volume is still low. Japan stock market has made strong trade regulations therefore it has strong impact on these equity markets.

Daily time series data of the stock markets of above selected Asian countries had been composed from yahoo finance and Market watch etc. It comprises the data of 13 years starting from January, 2001 to 2013 December. Having glance on the results shown by correlation matrix, it might be carefully said, it is evident that KSE-100 index has weak correlation with Malaysia, Taiwan, SSE and Nikkie-225.

We can conclude on the basis of these results that there are many opportunities for selection of securities in portfolios intended by the investors of these markets include China, Malaysia and Taiwan and Japan who showed weak correlation with KSE-100. The lower level of correlation always offers attraction for the foreign as well as institutional investor to get the benefit by of portfolio diversification by investing in these equity markets. As Chinese Stock Market has very low correlation with KSE-100 Index, so the investors may get a lot of benefit from of portfolio diversification (PD) by investing in this equity market. As same way, the increased correlation between stock markets reduces the opportunities for portfolio diversification. It conveys that the benefits of diversification which truly exists which is beneficial for fund manager.

It is evident that correlation analysis does not considering any cause and effect relationship it's merely discussed the strength as well as direction of the relationship. For better understanding Co-integration analysis test which is performed to calculate the long term comovement of stock price indices. The stationarity of the data was tested through Augmented Dickey Fuller test (1981) before the applying of J and J (1991) co-integration Approach. The stationarity of these time series data were been tested by applying said test, which in venerated that the series were integrated on level as well as 1st difference i.e. I (1).

To investigate the long term co-movement or relationship Cointegration Approach as used by Johnson and Julius (1991) was applied. Two test i.e. Trace Statistics as well as Maximum Eigen value test confirmed results of Co-integration analysis. The result for T-Statistics demonstrated there present no Co-integration vectors at 0.05 critical levels $(5 \%$ level) similarly the Maximum Eigenvalue Tests also confirmed that. Hence proved by the co-integration (Johnson and Julius (1991) Approach), it is to discover there is no long-term co-integration relationship among KSE-100 index Pakistani stock market and Nikkie-225, SSE, KLSE, and TSEC.To investigate the short term positive or negative impact and significance (VECM) was applied. To further examine the co-movement among the Selected Asian and KSE-100 index Pakistani stock markets. The result showed that though Nikkie-225, SSE and TSEC have not longterm relationship among these markets but it has short term relationship exist.

\section{Limitations and future recommendations}

This study is conducted in a limited span of time and to check the co-integration. After studying the previous researches on cointegration in Asian markets especially in my selected sample there is little work being available in which these markets are studied together. So it can be emerging topic for further research to analyze co-integration and volatility in these markets or causality and contagion may provide some further interesting results relating to the degree of integration amongst the equity markets of Southeast Asia by using different econometric techniques.

Additional study which may disclose that there might be further economic variables which can cause financial as well as economic integration, like interest rate differentials, foreign direct investment, GDP, portfolio investment, inflation rate, stock market capitalization ratio, money supply, etc. It is recommended, to investigate and identify those factors between two stock markets that may lead towards financial as well as economic integration a detailed study is to be required.

\section{References}

Aamir Shah, S. M., Husnain, M., \& Ali, A. (2012). Is Pakistani Equity Market Integrated to the Equity Markets of Group of Eight (G8) Countries? An Empirical Analysis of Karachi Stock Exchange. Romanian Economic Journal,15(45).

Abbas, Q., Khan, S., \& Shah, S. Z. A. (2013). Volatility transmission in regional Asian stock markets.Emerging Markets Review, 16, 66-77.

Abdalla, S. Z. S. (2012). Modelling Stock Returns Volatility: Empirical Evidence from Saudi Stock Exchange.International Research Journal of Finance and Economics 85(166-179.

Agyei-Ampomah, S. (2011).Stock market integration in Africa. Managerial Finance, 37(3), 242-256.

Arouri, E.H.M., \& Nguyen, D.K. (2010). Time-varying characteristics of cross-market linkages with empirical application to Gulf stock markets. Managerial Finance, 36(1), 57-70.

Arshad.H, Shah. Z \& S. Abdullah (2007), "Testing Random Walks and Market Efficiency in an emerging equity market", Business Review Cambridge, volume 9 , pp271-281. 
Bekaert, Geert, and Campbell R. Harvey. (1997) "Emerging equity market volatility." Journal of Financial economics 43.1 : 29-77.

Chancharat, S., \&Valadkhani, A. (2007).An empirical analysis of the Thai and major international stock markets. Faculty of Commerce-Economics Working Papers, 178.

Cheng, A.-R., Jahan-Parvar, M. R. \& Rothman, P. 2010. An Empirical Investigation of Stock Market Behavior in the Middle East and North Africa. Journal of Empirical Finance 17(3): 413-427.

Chung JP \& Liu JP (1994).Common Stochastic trends in Pacific Rim Stock Markets. Q. Rev. Econ. Financ., 34(3): 241-259.

Dickey DA, Fuller WA (1981). Likelihood Ratio Statistics for Autoregressive Time Series with Unit Root. Econometrica, 49:1057-1072.

Engle, R.F. \& Granger, C. (1987), "Co-Integration, error correction: Representation, estimation and testing”, Econometrica, Vol. 55, pp 12511276.

Ewing, B. T. (2002). The Transmission of Shocks among S\&P Indices. Applied Financial Economics 12(4): 285-290.

Fan, K., Lu, Z., \& Wang, S. (2009). Dynamic Linkages Between the China and International Stock Markets. Asia-Pacific Financial Markets, 16(3), 211-230. doi:10.1007/s10690-009-9093-5

Gallo, G. M., \& Otranto, E. (2007). Volatility transmission across markets: a Multichain Markov Switching model. Applied Financial Economics, 17(8), 659-670.

Glezakos M., Merika A., \& Kaligosfiris. H. (2007). Interdependence of major world stock exchanges: How is the Athens stock exchange affected? International Research Journal of Finance and Economics, 7.

Granger CWJ (1988).Some recent developments in a concept of causality. J. Econom., 39 (1/2): 199-211.

Hamid, K. (2011). Casual and dynamic linkage of stock markets: An empirical study of Karachi Stock Exchange (KSE) with emerging and developed equity markets. African Journal of Business Management, 5(19). doi:10.5897/AJBM10.1145

Hamilton, J. D., \& Lin, G. (2009). Stock market volatility and the business cycle. Journal of Applied Econometrics, 11(5), 573-593.

Hasan, A., Saleem, H. M., \& Abdullah, M. S. (2008), "Long-Run Relationships between an Emerging Equity Market and Equity Markets of the Developed World an Empirical Analysis of Karachi Stock Exchange", International Research Journal of Finance and Economics, Vol. 16:52-62

Hasan A, Durrani KT (2008). Causal and dynamic relationship among equity markets of South Asia. Jinnah Bus. Rev., 1(1): 39-49.

Hee Ng, T. (2002). Stock Market Linkages in South-East Asia. Asian Economic Journal, 16(4), 353-377.

Hoque, H. (2007), “Co-movement of Bangladesh stock market with other markets: Co- integration and error correction approach", Journal of Managerial Finance, Vol. 33, pp. 810-820.

Hussain, R. Y., Hussain, H., Bhatti, G. A., \& Hassan, A. (2012). Long run Relationship among East Asian equity markets and KSE. Management Science Letters, 2(4), 1167-1174. doi:10.5267/j.msl.2012.03.004

Islam, M. I., Rahimian, E., \& Robbani, M.G. (2005). Interdependence of the equity markets of India, Malaysia and Singapore: Tests based on daily equity series. Investment Management and Financial Innovations, 4, 95104.

Janakiramanan S,\& Lamba SA (1998). An empirical examination of linkages between Pacific-Basin stock markets. J. Int. Financ. Mark., Inst. Money, 8:155-17

Johansen S, Juselius K (1990). Maximum likelihood estimation and inference on co-integration with application to the demand for money. Oxf. Bull. Econ. Stat., 52:169-209.

Johansen S (1991). Estimation and hypothesis testing of co-integrating vectors in Gaussian vector autoregressive models. Econometrica, 59(11): 15511580 .
Kasa, K. (1992), "Common stochastic trends in international stock markets", Journal of Monetary Economics, Vol. 29, pp.95-124.

Khan, S. N., \& Aslam, M. S. (2014). Co-integration of Karachi Stock Exchange with major South Asian Stock Exchanges. International Journal of Accounting and Financial Reporting, 4(1).

Malik, S., Hussain, S., \& Ahmed, S. (2009). Impact of political event on trading volume and stock returns: The case of KSE. International Review of Business Research Paper, 5(4), 354-364.

Marashdeh, H. (2005). Stock market integration in the MENA region: An application of the ARDL bounds testing approach. Working Paper, November 2005.

Markowitz, H. (1952). Harry M. Markowitz. Portfolio selection, Journal of Finance, 7(1), 77-91.

Mustafa, K., \&Nishat, M. (2010). Risk, return and trading volume relationship in an emerging stock market: a case study of Karachi stock exchange. Savings and Development, 147-168.

Mustafa, M. J. (2012). Short-Run and Long-Run Dynamics Linkages among the Saudi Arabia Stock Market Indices.

Narayan P, Smyth R, Nandha M, (2004). Interdependence and dynamic linkages between the emerging stock markets of South Asia.Account.Financ., 44: 419-439.

Phillips, P. \&Perron, P.(1988),'Testing for a unit root in time series regression", Biometrica, Vol.75, pp.335-346.

Qayyum, A., \& Kemal, A. R. (2006).Volatility spillover between the stock market and the foreign exchange market in Pakistan. Retrieved from http://mpra.ub.uni-muenchen.de/1715/?referer=www.clickfind.com.au

Rahman, M. L., \&Uddin, J. (2009). Dynamic relationship between stock prices and exchange rates: evidence from three South Asian countries. International Business Research, 2(2), P167.

Rajwani, S., \& Mukherjee, J. (2013). Is the Indian stock market co-integrated with other Asian markets? Management Research Review, 36(9), 899918.

Roca, E.(1999)," Short-term and long-term price linkages between the equity markets of Australia and its major trading partners", Applied Financial Economics, Vol. 9,pp. 501 -511.

Searat. A , Zaheer. B, ( 2011). "Co-movement between emerging and developed stock market, ” journal of applied sciences ,12(4): 395-403.

Shahbaz, M., Ahmed, N., \& Ali, L. (2008). Stock market development and economic growth: ARDL causality in Pakistan. International Research Journal of Finance and Economics, 14(1), 182-195.

Sheng HC, \&Tu AH (2000).A study of co-integration and variance decomposition among national equity indices before and during the period of the Asian financial crisis. J. Multinational Finan. Manage., 10: 345-365.

Smyth, N. and Nandha, M. (2004), "Interdependence and dynamic linkages between the emerging stock markets of South Asia", Accounting and Finance, Vol. 44,pp,419-439.

Sohail, N., \&Hussain, Z. (2009). Long-Run and Short-Run Relationship between Macroeconomic Variables and Stock Prices in Pakistan: The Case of Lahore Stock Exchange. Pakistan Economic and Social Review, 183-198.

Subhani, M. I., Hasan, D., Akif, S., Mehar, D., \& Osman, M. (2011). Are the major South Asian equity markets co-integrated? International Journal of Humanities and Social Science, Vol. 1, No. 12 (2011): pp. 117-121.

Subramanian, U. (2008). Cointegration of stock markets in East Asia.European Journal of Economics, Finance and Administrative Sciences, 14, 84-92.

Suchismita B, Paramita, M (2006). A study of Inter linkages between the Indian Stock Market and some other emerging and developed markets.9th Capital Market Conference Paper, Indian Institute of Capital Markets India. 